\title{
HEPATIC ARTERIAL PATTERN AND CELIAC TRUNK NOT DESCRIBED IN LITERATURE
}

\author{
Victor Antonio Kuiava1 ${ }^{1}$ Ana Thereza Perin ${ }^{1}$, Daniel Navarini ${ }^{1,2,3}$, \\ Senair Alberto Ambros ${ }^{1,2,4}$, Mateus Picada Correa ${ }^{1,2,5}$
}

\begin{abstract}
Knowledge of the hepatic arterial anatomy and celiac trunk is gaining importance, since the use of minimally invasive surgeries is more frequent nowadays. This kind of procedure meant that surgeons had less room for visualization of anatomical variants and work. In addition, failure to recognize the correct anatomy of the hepatic vascularization in a transplant procedure can lead to organ failure and death. The present case aims to demonstrate an arterial hepatic celiac trunk pattern that was never described by any of the acknowledged classification systems. This pattern is challenging for the surgical management of possible upper abdominal interventions, since non-recognition may lead to iatrogenesis.
\end{abstract}

Keywords: Hepatic artery; mesenteric artery; superior; celiac artery; anatomy

The knowledge of the hepatic arterial anatomy is fundamental since there has been an improvement of minimally invasive techniques, which has brought reduced visualization space for the surgeon. In addition, liver transplant techniques are fundamentally based on this anatomy. Knowing the patterns of anatomical variation of the hepatic system is of fundamental importance ${ }^{1,2}$.

The hepatic arterial vascularization system is mostly dependent on irrigation of the right and left hepatic arteries, branches of the common hepatic artery, which originates from the celiac trunk. The celiac trunk originates three arteries: left gastric, common hepatic and splenic. This is the usual conformation found in $86.8 \%$ of the patients analyzed ${ }^{3,4}$.

The most common anatomical alterations of this system are the presence of an accessory or substitutive right hepatic artery of the superior mesenteric artery $(6.05 \%)$, followed by an accessory or substitute left hepatic artery that comes from the left gastric artery (3.34\%). However, the present case does not fit into any hepatic arterial system proposed in studies ${ }^{5}$.

\section{CASE REPORT}

A 26-year-old male patient is submitted in 2016 to abdominal computed tomography with iodinated contrast. When analyzing the plans of reconstruction in three dimensions it is noticed that the hepatic arterial system and the celiac trunk does not follow the usual pattern.

In the image presented, the patient does not have the celiac trunk; however, he has the left gastric artery originating directly from the abdominal aorta, which originates an accessory left hepatic artery; a right hepatic artery, which originates directly from the abdominal aorta; and a hepatosplenic trunk - originating the splenic artery and the common hepatic artery. The superior mesenteric artery does not present alterations. See Figures 1 and 2.

\section{DISCUSSION}

The usual anatomy of the celiac trunk and the hepatic arterial system consists of the presence of three arteries originating from the celiac trunk, which are the left gastric, the splenic, and the common hepatic artery ${ }^{6,7}$. In turn, the common hepatic artery bifurcates in two, a hepatic of its own - which will
Clin Biomed Res. 2018;38(3):305-307

1 Faculdade de Medicina, Universidade de Passo Fundo (UPF). Passo Fundo, RS, Brasil.

2 Hospital São Vicente de Paulo (HSVP). Passo Fundo, RS, Brasil.

3 Clínica Gastrobese. Passo Fundo, RS, Brasil.

4 Centro de Diagnostico, Hospital São Vicente de Paulo (HSVP). Passo Fundo, RS, Brasil.

5 Instituto Vascular (INVASC). Passo Fundo, RS, Brasil.

Corresponding author: Victor Antonio Kuiava victorkuiava@gmail.com Faculdade de Medicina, Universidade de Passo Fundo (UPF)

Rua Teixeira Soares, Centro, 817 99010-080, Passo Fundo, RS, Brasil. 


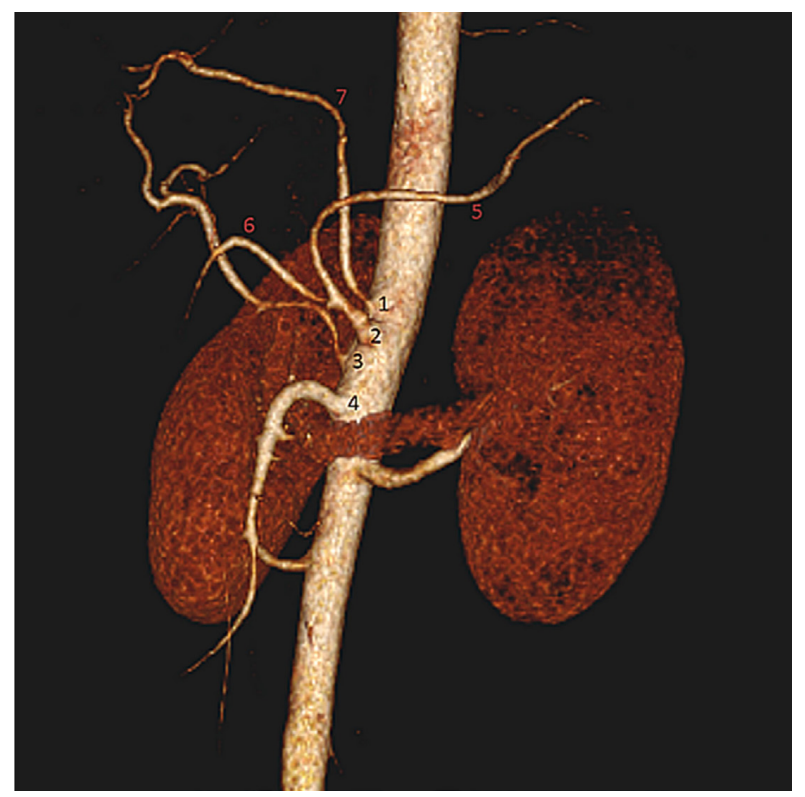

Figure 1: Abdominal angiotomography with lateral reconstruction in 3D - Unusual Anatomy. 1) left gastric artery, 2) hepatosplenic trunk, 3) right hepatic artery, 4) The superior mesenteric artery, 5) splenic artery, 6) common hepatic artery, 7) left gastric artery.

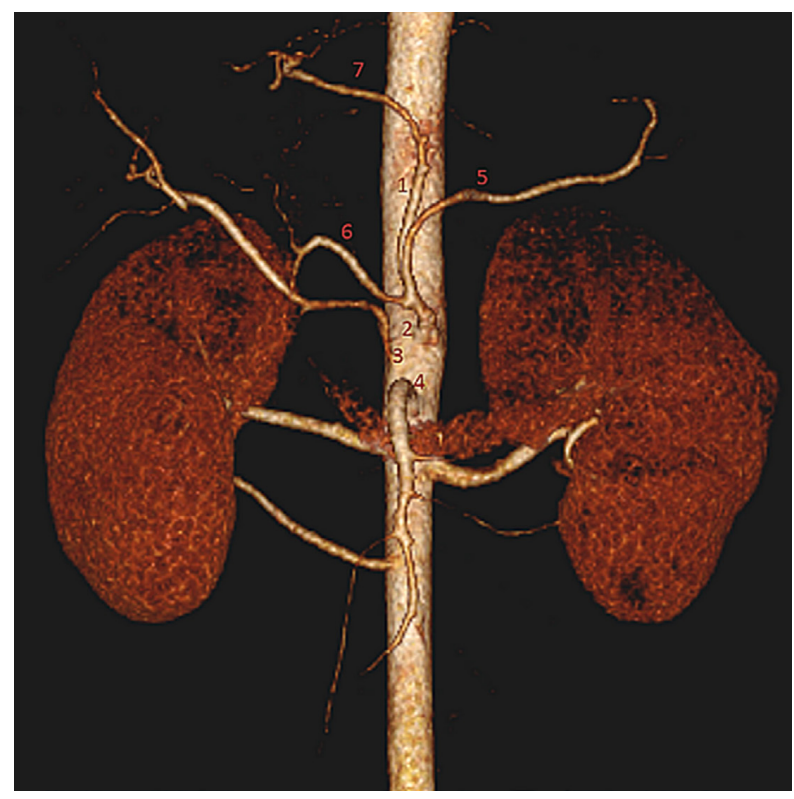

Figure 2: Abdominal angiotomography with 3D reconstruction in frontal position - Unusual Anatomy. 1) left gastric artery, 2) hepatosplenic trunk, 3) right hepatic artery, 4) the superior mesenteric artery, 5) splenic artery, 6) common hepatic artery, 7) left gastric artery.

give rise to the right and left hepatic arteries - and a gastroduodenal artery, as shown in Figure 3.

Vascular changes in hepatic arteries are found in $21 \%$ of patients. They are alterations in the hepatic

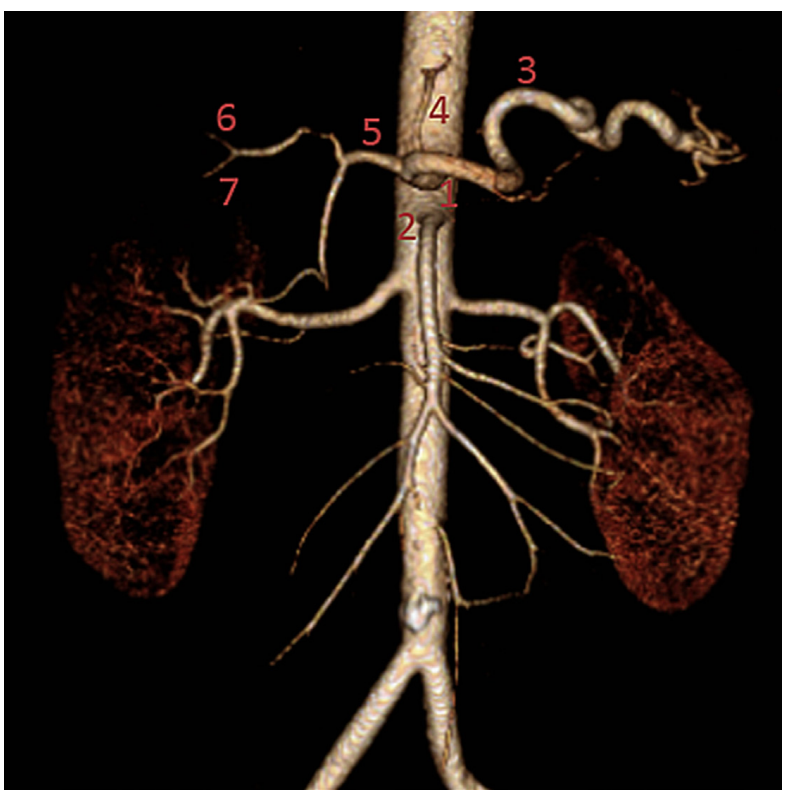

Figure 3: Abdominal angiotomography with 3D reconstruction in frontal position - Normal Anatomy. 1) celiac trunk, 2) the superior mesenteric, 3) splenic artery, 4) left gastric artery, 5) common hepatic artery, 6) left hepatic artery, 7) right hepatic artery.

circulation, with could be either accessory or substitutive arteries. The most acknowledged patterns are the presence of a right hepatic artery originating from the superior mesenteric and/or a left hepatic branch of the left gastric artery ${ }^{2}$.

In the largest study of the celiac trunk and hepatic arterial system variations conducted with 5002 patients in Korea, the presented arterial conformation was not described. This vascular pattern may be a problem for surgeries involving the upper abdominis, since the anatomical difference is enormous, with no description of this circulatory pattern ${ }^{6}$.

Arterial variations occur due to deviations from the normal pattern of embryogenesis, leading to peculiar vascular formations. Generally, these changes do not cause significant clinical repercussion, however in special situations or in surgical management they may induce iatrogenesis ${ }^{7,8}$.

The main complications are related to the non-recognition of abnormal arterial branches, such as the right hepatic artery branch of the superior mesenteric artery, whose location passes through the retroportal space. This conformation may lead to iatrogenesis during surgery, such as unnecessary clamping ${ }^{1}$.

The viability of a liver transplant is closely related to the success of vascular anastomoses performed. Vascular complications are the main etiological diagnosis for fulminant organ failure, fistulas and 
bacteremia without etiologic cause. The hepatic artery is the second most common vascular site of vascular complications in transplantation. Its most common complications are thrombosis, which happens in $15.8 \%$ of cases and stenosis, in $7.8 \%$. When present, they are associated with loss of organ in $53 \%$ and mortality in $33-50 \%$ of patients ${ }^{9,10}$.

Preoperative imaging studies in hepatic transplantation are fundamental for analysis of the vascular system, both arterial and venous. The correct analysis of anatomical variations allows the reduction of surgical unexpected situations by the surgeon, which are sometimes difficult to manage or impossible to transplant ${ }^{11,12}$. This evaluation is usually performed by angiotomography with arterial, portal and late analysis or by celiac and mesenteric angiography for the hepatic and portal vein arteries or by magnetic resonance imaging for venous, portal and bile duct drainage, but the latter modality has a worse anatomical resolution than the previous two ${ }^{13}$.

The surgical management of these situations of anatomical variations in liver transplantation begins primarily with the preoperative identification of these patterns through imaging tests. At the surgical moment, these variations are managed with resection of the organ with a large margin of hepatic tissue with extensions of the hepatoduodenal ligament, celiac trunk, accessory hepatic arteries, and right and left hepatic artery. Larger removals of hepatic tissue and perihepatic tissues decrease the possibility of vascular injury, reducing complications such as thrombosis and stenosis of the hepatic artery ${ }^{12}$.

\section{Conflicts of Interest}

The authors declare no conflicts of interest.

\section{REFERENCES}

1. Araujo SA No, Franca HA, Mello CF Jr, Silva EJ No, Negromonte GRP, Duarte CMA, et al. Anatomical variations of the celiac trunk and hepatic arterial system: an analysis using multidetector computed tomography angiography. Radiol Bras. 2015;48(6):358-62. http://dx.doi org/10.1590/0100-3984.2014.0100. PMid:26811552.

2. Koops A, Wojciechowski B, Broering DC, Adam G, Krupski-Berdien G. Anatomic variations of the hepatic arteries in 604 selective celiac and superior mesenteric angiographies. Surg Radiol Anat. 2004;26(3):239-44. http://dx.doi.org/10.1007/s00276-0040229-z. PMid:14968265.

3. Moore KL, Agur AMR, Dalley AF. Anatomia orientada para a clínica. 7th ed. Rio de Janeiro: Guanabara Koogan; 2014.

4. Hiatt JR, Gabbay J, Busuttil RW. Surgical anatomy of the hepatic arteries in 1000 cases. Ann Surg. 1994;220(1):50-2. http://dx.doi. org/10.1097/00000658-19940700000008. PMid:8024358.

5. Sebben GA, Rocha SL, Sebben MA, Parussolo PR, Fo, Gonçalves $\mathrm{BH}$. Variations of hepatic artery: anatomical study on cadavers. Rev Col Bras Cir. 2013;40(3):221-
6. http://dx.doi.org/10.1590/ S0100-69912013000300010. PMid:23912370.

6. Song S-Y, Chung JW, Yin YH, Jae $\mathrm{HJ}$, Kim H-C, Jeon UB, et al. Celiac axis and common hepatic artery variations in 5002 patients: systematic analysis with spiral CT and DSA. Radiology. 2010;255(1):278-88. http:// dx.doi.org/10.1148/radiol.09090389. PMid:20308464.

7. Prakash, Rajini T, Mokhasi V, Geethanjali BS, Sivacharan PV, Shashirekha M. Celiac trunk and its branches: anatomical variations and clinical implications. Singapore Med J. 2012;53(5):329-31. PMid:22584973.

8. lezzi R, Cotroneo AR, Giancristofaro D, Santoro M, Storto ML. Multidetector-row CT angiographic imaging of the celiac trunk: anatomy and normal variants. Surg Radiol Anat. 2008;30(4):303-10. http://dx.doi. org/10.1007/s00276-008-0324-7. PMid:18286222.

9. Piardi $\mathrm{T}$, Lhuaire $\mathrm{M}$, Bruno $\mathrm{O}$, Memeo $R$, Pessaux P, Kianmanesh R, et al. Vascular complications following liver transplantation: A literature review of advances in 2015. World J Hepatol. 2016;8(1):36-57. http:// dx.doi.org/10.4254/wjh.v8.i1.36. PMid:26783420.
10. Orlandini MSG, Zanotelli ML. Complicações vasculares póstransplante hepático pediátrico: incidência e fatores de risco [dissertação]. Porto Alegre: Universidade Federal do Rio Grande do Sul; 2010.

11. Dazzi FL, Ribeiro MA JR, Mancero JM, Gonzalez AM, Leão-Filho HM, de Oliveira e Silva A, et al. Are the imaging findings used to assess the portal triad reliable to perform living-donor liver transplant? Arq Bras Cir Dig. 2013;26(4):296301. http://dx.doi.org/10.1590/ S0102-67202013000400009. PMid:24510038.

12. Dong JH. Management of vascular anomalies and complications in liver transplantation. Hepatobiliary Pancreat Dis Int. 2005;4(3):330-1. PMid:16109510.

13. Eubank WB, Wherry KL, Maki JH, Sahin H, Funkhouser CP, Schmiedl UP. Preoperative evaluation of patients awaiting liver transplantation: comparison of multiphasic contrastenhanced 3D magnetic resonance to helical computed tomography examinations. J Magn Reson Imaging. 2002;16(5):565-75. http:// dx.doi.org/10.1002/jmri.10194. PMid:12412034.

Received: Jul 10, 2018 Accepted: Aug 21, 2018 